\title{
PENINGKATAN KEMAMPUAN BERPIKIR LOGIS PESERTA DIDIK MELALUI MODEL PEMBELAJARAN ADVANCE ORGANIZER DENGAN BANTUAN MEDIA INDEX CARD MATCH
}

\author{
Nurul Husna ${ }^{1}$ \\ ${ }^{I}$ MTs. Sunan Ampel Siman Kediri \\ Email: ${ }^{1}$ husnaarif071@gmail.com
}

\begin{abstract}
Abstrak
Penelitian ini bertujuan untuk mendeskripsikan proses peningkatan kemampuan berpikir logis peserta didik melalui model pembelajaran Advance Organizer dengan bantuan media Index Card Match kelas VIIC MTs. Sunan Ampel Siman materi belah ketupat dan layang-layang tahun pelajaran 2016/2017. Penelitian ini menggunakan pendekatan kualitatif dengan jenis penelitian tindakan kelas. Setiap siklus terdiri dari perencanaan, pelaksanaan, pengamatan, dan refleksi. Teknik pengumpulan data terdiri dari: tes, observasi, wawancara, dan catatan lapangan. Teknik analisis data dalam penelitian ini dibagi menjadi dua, yaitu analisis data kualitatif dan analisis data kuantitatif. Hasil penelitian menunjukkan bahwa ada proses peningkatan kemampuan berpikir logis peserta didik melalui model pembelajaran Advance Organizer dengan media Index Card Match kelas VIIC MTs. Sunan Ampel Siman materi belah ketupat dan layang-layang tahun pelajaran 2016/2017. Deskripsi peningkatannya adalah (1) ketuntasan pada tes akhir siklus I sebesar 66,67\% dengan nilai rata-rata kelas mencapai 73,67. Sedangkan pada siklus II mencapai $77,78 \%$ dengan nilai rata-rata 78,52; (2) hasil observasi kesesuaian kegiatan guru dengan Rencana Pelaksanaan Pembelajaran (RPP) pada siklus I mencapai 85,95\% sedangkan pada siklus II mengalami peningkatan menjadi 87,62\%; (3) hasil observasi kesesuaian aktivitas siswa dengan Rencana Pelaksanaan Pembelajaran (RPP) pada siklus I mencapai 80,95\% sedangkan pada siklus II menjadi $87,38 \%$; (4) hasil persentase wawancara dari 6 peserta didik pada siklus I mencapai $66,67 \%$ yaitu 4 dari 6 peserta didik menyatakan senang dan pada siklus II menjadi 83,33\% yaitu 5 dari 6 peserta didik menyatakan senang dengan penerapan model pembelajaran Advance Organizer dengan media Index Card Match.
\end{abstract}

Kata Kunci: model pembelajaran Advance Organizer, media Index Card Match, kemampuan berpikir logis.

\section{PENDAHULUAN}

Matematika merupakan pelajaran wajib di sekolah mulai dari sekolah dasar sampai perguruan tinggi, namun pelajaran matematika dianggap masih menyulitkan untuk dipelajari bagi peserta didik. Pembelajaran matematika pada kurikulum 2013 ini, diharapkan dapat meningkatkan kemampuan berpikir peserta didik. Tujuan pembelajaran matematika di jenjang pendidikan dasar dan menengah adalah untuk mempersiapkan dan membekali peserta didik dengan kemampuan berpikir logis, analitis, sistematis, kritis, dan kreatif serta kemampuan bekerjasama (Ibrahim dan Suparni, 2008:36). Kemampuan berpikir yang akan ditingkatkan yaitu kemampuan berpikir logis peserta didik, artinya kemampuan peserta didik dalam berpikir menemukan suatu kebenaran berdasarkan dengan logika tertentu.

Siswono (dalam Budi dan Mega, 2014:43) mengatakan berpikir logis dapat diartikan sebagai kemampuan peserta didik untuk menarik kesimpulan yang sah menurut aturan logika dan dapat membuktikan kesimpulan itu benar (valid) sesuai dengan pengetahuan-pengetahuan sebelumnya yang sudah diketahui. Ni'matus (dalam Budi dan Mega, 2014:43) menyatakan indikator dari berpikir logis antara lain: (1) Keruntutan berpikir, dimana peserta didik dapat menentukan langkah 
yang ditempuh dengan teratur. (2) Kemampuan berargumen, dimana peserta didik dapat memberikan argumennya secara logis. (3) Penarikan kesimpulan, dimana peserta didik dapat menarik kesimpulan dari suatu permasalahan yang ada.

Namun kenyataannya pada saat peneliti memberikan soal tes kemampuan berpikir logis, peserta didik kesulitan dalam menjawab soal. Dalam menjawab soal yang diberikan, peserta didik masih belum dapat memberikan jawaban yang tepat dan menyimpulkan hasil pekerjaannya. Dan setelah soal yang dikerjakan peserta didik dianalisis, ternyata terlihat bahwa kemampuan berpikir logis peserta didik sangat rendah. Sebanyak $40 \%$ nilai rata-rata peserta didik masih di bawah kriteria keberhasilan kemampuan berpikir logis peserta didik. Berdasarkan wawancara peneliti dengan guru matematika MTs Sunan Ampel Siman yaitu Ibu Dumiasri, S.Pd mengatakan hasil ulangan dan UTS (Ujian Tengah Semester) peserta didik, rata-rata nilai peserta didik sebanyak 37\% masih dibawah SKBM (Standar Ketuntasan Belajar Minimum). Sehingga perlu adanya suatu solusi untuk meningkatkan cara berpikir logis peserta didik.

Permasalahan ini timbul dikarenakan pemilihan model pembelajaran yang kurang sesuai dengan pembelajaran matematika. Model pembelajaran tersebut harus dapat membantu peserta didik dalam menguasai konsep serta mendorong peserta didik untuk menerapkannya dalam kehidupan sehari-hari. Model yang akan digunakan dalam penelitian ini yaitu model pembelajaran Advance Organizer. Dengan model ini, peserta didik mampu mengintegrasikan materi lama dengan materi baru dan juga dapat memperluas pemahaman konsep peserta didik. Menurut Weil dan Joyce (dalam Basleman dan Mappa 2011:91), teori pembelajaran model Advance Organizer dikembangkan oleh Ausubel, seorang pakar luar biasa di antara para pakar teori pendidikan. Menurut Huda (2013:107) model Advance Organizer ini dirancang untuk memperkuat struktur kognitif peserta didik. Yang dimaksud dengan struktur kognitif adalah pengetahuan peserta didik tentang pelajaran tertentu dan bagaimana mengelola, memperjelas, dan memelihara pengetahuan tersebut dengan baik.

Dengan langkah-langkah pembelajaran sebagai berikut. (a) Presentasi Advance Organizer, guru membahas materi yang baru dengan mengaitkan materi yang sebelumnya. Kemudian guru membagi peserta didik dalam beberapa kelompok dan membagikan Lembar Kegiatan Peserta Didik (LKPD) serta media Index Card Match berupa kartu soal dan jawaban, (b) Penyajian tugas belajar, peserta didik memasangkan kartu soal dengan kartu jawaban yang cocok bersama dengan teman sekelompoknya berdasarkan jawaban yang sesuai pada LKPD yang telah dibagikan, (c) Penguatan organisasi kognitif, peserta didik mempresentasikan hasil diskusinya di depan kelas dan peserta didik diminta untuk menjelaskan hasil jawabannya dengan mengaitkan materi lama dengan materi baru.

Agar peserta didik lebih mengerti dan aktif dalam berpikir logis, maka diperlukan bantuan media pembelajaran yang menarik. Media yang digunakan untuk mendampingi model pembelajaran yang digunakan pada saat penelitian adalah Media Index Card Match. Media ini dapat memancing peserta didik untuk aktif berpikir dan suasana kelas menjadi menyenangkan. Dengan adanya media ini, peserta didik dapat memahami materi yang sedang dibahas dengan menghubungkan kartu-kartu yang sudah tersedia. Index Card Match merupakan suatu media yang bermakna yang dapat melatih rasa tanggung jawab dan penguasaan materi yang telah dipelajari serta melatih pemahaman konsep peserta didik terhadap materi yang telah dipelajari melalui pencarian kartu (Ardayati, 2015:27). Dalam pemanfaatan media Index Card Match ini akan terdapat dua bagian kartu yaitu kartu soal dan kartu jawaban.

Tujuan penelitian ini adalah untuk mendeskripsikan proses peningkatan kemampuan berpikir logis peserta didik melalui model pembelajaran Advance Organizer dengan bantuan media Index Card Match kelas VIIC MTs. Sunan Ampel Siman materi belah ketupat dan layang-layang tahun pelajaran 2016/2017. 


\section{METODE}

Pendekatan yang digunakan dalam penelitian ini adalah pendekatan kualitatif dan pendekatan kuantitatif. Penelitian tindakan kelas dapat diartikan sebagai proses pengkajian masalah pembelajaran di dalam kelas melalui refleksi diri dalam upaya untuk memecahkan masalah tersebut dengan cara melakukan berbagai tindakan yang terencana dalam situasi nyata serta menganalisis setiap pengaruh dari perlakuan tersebut (Sanjaya, 2009:26). Menurut Arikunto (2014:17) terdapat 4 tahap yang lazim dilalui dalam penelitian tindakan kelas, yaitu: (1) Perencanaan ( planning), (2) Pelaksanaan (acting), (3) Pengamatan (observing), dan (4) Refleksi (reflecting).

Penelitian ini dilakukan di MTs. Sunan Ampel Siman yang berada di Jl. Harinjing No. 269 RT/RW 07/01 Juwah Siman Kepung Kediri. Subyek penelitian ini adalah peserta didik kelas VIIC MTs. Sunan Ampel Siman pada semester genap tahun ajaran 2016/2017.

Teknik pengumpulan data yang digunakan adalah sebagai berikut: (1) Tes, (2) Observasi, (3) Wawancara, dan (4) Catatan lapangan. Teknik analisis data dalam penelitian ini dibagi menjadi dua, yaitu analisis data kualitatif dan analisis data kuantitatif. Menurut Miles dan Huberman (dalam Sugiyono, 2015:338-345), data kualitatif dianalisis dengan menggunakan teknik analisis data yang terdiri dari reduksi data, data display (penyajian data), dan kesimpulan (conclusion drawing/verification). Sedangkan data kuantitatif dianalisis dengan mencari nilai rata-rata dan presentase dari tes akhir siklus.

Pengecekan keabsahan data dimaksud untuk memperoleh tingkat kepercayaan yang berkaitan dengan seberapa jauh kebenaran hasil penelitian, mengungkapkan, dan memperjelas data dengan fakta-fakta aktual di lapangan. Menurut Moleong (2014: 327), kriteria derajat kepercayaan dilakukan dengan 7 cara, diantaranya: (1) perpanjangan keikutsertaan; (2) ketekunan pengamatan; (3) triangulasi; (4) pengecekan sejawat; (5) kecukupan referensial; (6) kajian kasus negatif; dan (7) pengecekan anggota. Dalam penelitian ini, peneliti akan menggunakan 3 cara, yakni sebagai berikut: (1) ketekunan pengamatan, (2) triangulasi, dan (3) pengecekan sejawat.

Menurut Hopkins (dalam Sanjaya, 2009:53), pelaksanaan tindakan yang dilakukan membentuk spiral dimulai dari merasakan adanya masalah menyusun perencanaan, melaksanakan tindakan, melakukan observasi, mengadakan refleksi, melakukan rencana ulang, melaksanakan tindakan, dan seterusnya. Adapun model dan penjelasan tahapannya adalah sebagai berikut.

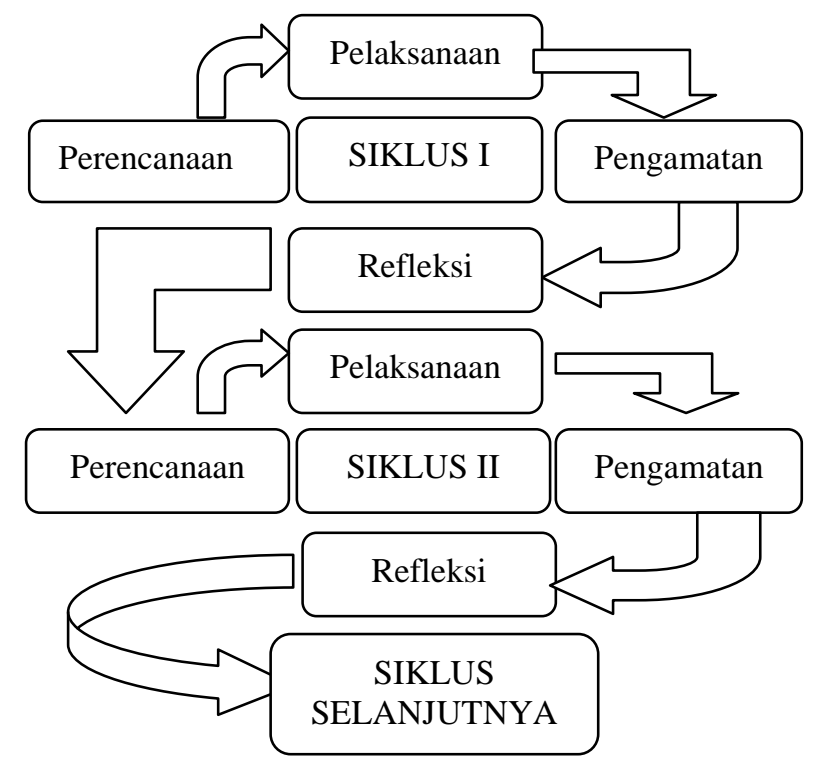

Bagan 1. Siklus Penelitian Tindakan (Sumber: Arikunto, 2012:16) 
Penelitian ini dikatakan berhasil jika sudah memenuhi kriteria keberhasilan yang ditentukan oleh peneliti. Kriteria keberhasilan meliputi keberhasilan proses dan hasil. Adapun kriteria keberhasilan siklus dapat dilihat pada Tabel 3.2.

Tabel 1. Kriteria Keberhasilan Tindakan

\begin{tabular}{|c|c|c|c|}
\hline Kriteria Keberhasilan & Instrumen & $\begin{array}{l}\text { Teknik } \\
\text { Pengumpulan } \\
\text { Data }\end{array}$ & Analisis Data \\
\hline $\begin{array}{l}\text { Nilai rata-rata kelas tes } \\
\text { peserta didik } \geq 75\end{array}$ & $\begin{array}{l}\text { Lembar soal tes } \\
\text { akhir siklus }\end{array}$ & Tes & \multirow{2}{*}{$\begin{array}{l}\text { Analisis data } \\
\text { kuantitatif, kemudian } \\
\text { membandingkan } \\
\text { dengan taraf } \\
\text { keberhasilan } \\
\end{array}$} \\
\hline $\begin{array}{l}\geq 75 \% \text { peserta didik } \\
\text { mendapat nilai tes } \geq 75\end{array}$ & $\begin{array}{l}\text { Lembar soal tes } \\
\text { akhir siklus }\end{array}$ & Tes & \\
\hline $\begin{array}{l}\text { Persentase keberhasilan } \\
\text { tindakan } \geq 81 \%\end{array}$ & $\begin{array}{l}\text { Lembar } \\
\text { observasi } \\
\text { kegiatan guru } \\
\text { dan lembar } \\
\text { observasi } \\
\text { aktivitas peserta } \\
\text { didik }\end{array}$ & Observasi & $\begin{array}{l}\text { Analisis data } \\
\text { kualitatif, kemudian } \\
\text { membandingkan } \\
\text { dengan kriteria } \\
\text { keberhasilan }\end{array}$ \\
\hline $\begin{array}{l}\text { Peserta didik merasa senang } \\
\text { dengan model pembelajaran } \\
\text { Advance Organizer dengan } \\
\text { media Index Card Match } \geq \\
65 \% \text {. }\end{array}$ & $\begin{array}{l}\text { Pedoman } \\
\text { wawancara }\end{array}$ & Wawancara & $\begin{array}{l}\text { Analisis data } \\
\text { kualitatif, kemudian } \\
\text { membandingkan } \\
\text { dengan kriteria } \\
\text { keberhasilan }\end{array}$ \\
\hline
\end{tabular}

\section{HASIL}

Dalam subbab ini peneliti akan memaparkan data yang diperoleh selama penelitian tindakan kelas berlangsung dari tanggal 06 Mei 2017 sampai dengan tanggal 26 Mei 2017 di kelas VII MTs Sunan Ampel Siman. Hasil penelitian ini meliputi, (1) paparan data, (2) paparan data pelaksanaan siklus I, (3) paparan data pelaksanaan siklus II.

Pertama yang dilakukan peneliti dalam penelitian ini adalah menentukan lokasi dan subyek untuk penelitian. Peneliti menetapkan sekolah MTs. Sunan Ampel Siman yang berada di Jl. Harinjing No. 269 RT/RW 07/01 Juwah Siman Kepung Kediri sebagai lokasi penelitian. Selanjutnya pada hari Sabtu tanggal 06 Mei 2017 peneliti mendatangi MTs Sunan Ampel dan menemui Bapak Muda'i, S.Ag selaku Kepala MTs Sunan Ampel untuk meminta izin secara lisan tentang maksud dan tujuan peneliti. Selanjutnya Kepala Sekolah mempertemukan peneliti dengan salah satu guru mata pelajaran matematika yaitu Ibu Dumiasri, S.Pd untuk meminta bimbingan dalam mengadakan penelitian.

Peneliti sebelum memulai pelaksanaan tindakan terlebih dahulu mengadakan wawancara dengan guru matematika. Dari hasil wawancara tersebut peneliti dan guru menetapkan kelas VIIC untuk dijadikan kelas penelitian. Pada hari Senin tanggal 08 Mei 2017, Rabu tanggal 10 Mei 2017 dan Jum'at tanggal 12 Mei 2017 peneliti mengadakan observasi langsung di kelas VIIC pada saat pembelajaran matematika berlangsung. Kegiatan selanjutnya adalah peneliti memberikan lembar tes kemampuan berpikir logis pada saat observasi akhir pada hari Jum'at dan meminta hasil nilai matematika Ujian Tengah Semester (UTS) Genap peserta didik tahun pelajaran 2016/2017 kepada guru bidang studi matematika.

Berdasarkan informasi dari Ibu Dumiasri, S.Pd diketahui bahwa jumlah peserta didik di kelas VIIC adalah 27, dengan rincian 13 peserta didik laki-laki dan 14 peserta didik perempuan. Mata pelajaran matematika di kelas VIIC dilaksanakan selama tiga kali tatap muka dalam satu minggu. Adapun jadwal mengajar di kelas VIIC yaitu pada hari Senin jam ke 3-4 pukul (08.2009.40), hari Rabu jam ke 1-2 pukul (07.00-08.20), dan hari Jum'at jam ke 3 pukul (08.20-09.00). Dalam penelitian ini peneliti meminta bantuan Ibu Dumiasri, S.Pd sebagai pengamat pertama yang 
merupakan guru matematika di kelas VIIC MTs Sunan Ampel dan Aprina Natellee Abdullah sebagai pengamat kedua yang merupakan teman sejawat peneliti.

Teknik pengumpulan data yang digunakan adalah sebagai berikut: (1) Tes, (2) Observasi, (3) Wawancara, dan (4) Catatan lapangan. Teknik analisis data dalam penelitian ini dibagi menjadi dua, yaitu analisis data kualitatif dan analisis data kuantitatif. Hasil paparan data siklus I dan siklus II adalah sebagai berikut.

1. Persentase ketuntasan pada tes akhir siklus I sebesar $66,67 \%$ dengan nilai rata-rata kelas mencapai 73,67, sedangkan persentase tes akhir siklus II mengalami peningkatan sebesar $11,11 \%$ menjadi $77,78 \%$ dengan nilai rata-rata 78,52. Hal ini berarti dapat memenuhi kriteria taraf keberhasilan yang telah ditetapkan, dengan taraf keberhasilan dikategorikan baik.

2. Hasil observasi kesesuaian kegiatan guru dengan Rencana Pelaksanaan Pembelajaran (RPP) pada siklus I mencapai $85,95 \%$ sedangkan pada siklus II mengalami peningkatan sebesar 1,67\% menjadi $87,62 \%$. Hal ini berarti dapat memenuhi kriteria taraf keberhasilan yang telah ditetapkan, dengan taraf keberhasilan dikategorikan sangat baik.

3. Hasil observasi kesesuaian aktivitas peserta didik dengan Rencana Pelaksanaan Pembelajaran (RPP) pada siklus I mencapai 80,95\% sedangkan padasiklus II mengalami peningkatan sebesar $6,43 \%$ menjadi $87,38 \%$. Dari persentase yang didapat, hasil observasi telah mencapai taraf keberhasilan yang telah ditetapkan dengan taraf keberhasilan dikategorikan sangat baik.

4. Hasil persentase wawancara dari 6 peserta didik pada siklus I mencapai 66,67\% yaitu 4 dari 6 peserta didik menyatakan senang dengan penerapan model pembelajaran Advance Organizer dengan media Index Card Match dan pada siklus II mengalami peningkatan sebesar 16,67\% menjadi 83,33\% yaitu 5 dari 6 peserta didik menyatakan senang dengan penerapan model pembelajaran Advance Organizer dengan media Index Card Match. Dari persentase yang didapat, hasil wawancara telah mencapai taraf keberhasilan yang sangat baik.

5. Hasil catatan lapangan

Dari hasil catatan lapangan dapat disimpulkan bahwa peserta didik sudah mengikuti pembelajaran dengan baik, dengan indikasi kelas semakin kondusif, siswa lebih aktif dan adanya antusiasme belajar peserta didik terhadap model pembelajaran Advance Organizer dengan media Index Card Match.

\section{PEMBAHASAN}

Penerapan model pembelajaran Advance Organizer dengan media Index Card Match pada materi belah ketupat dan layang-layang dapat meningkatkan kemampuan berpikir logis peserta didik. Hal ini sejalan dengan pendapat Huda (2013:107) yang menagatakan bahwa "model Advance Organizer ini dirancang untuk memperkuat struktur kognitif peserta didik". Dan pendapat dari (Ardayati, 2015:27) yang menagatakan bahwa "Index Card Match merupakan suatu media yang bermakna yang dapat melatih rasa tanggung jawab dan penguasaan materi yang telah dipelajari serta melatih pemahaman konsep peserta didik terhadap materi yang telah dipelajari melalui pencarian kartu".

Dari hasil observasi dan refleksi pada siklus I, diperoleh informasi bahwa aktivitas peserta didik masih belum maksimal. Keadaan kelas masih belum kondusif, peserta didik masih kesulitan dan kebingungan dalam memahami maksud dari soal yang diberikan dan dalam menggunakan media Index Card Match yang telah disediakan. Hal ini dibuktikan dengan tes akhir siklus I dengan presentase ketuntasan mencapai 66,67\% dimana 18 dari 27 peserta didik yang hadir saat tes akhir siklus yang tuntas. Dengan demikian, penerapan model pembelajaran Advance Organizer dengan media Index Card Match pada pelaksanaan tindakan siklus I masih belum berhasil. Hal ini dikarenakan kriteria yang telah ditetapkan masih belum tercapai. Oleh karena itu, peneliti memperbaikinya pada tahap pelaksanaan tindakan siklus II.

Pada pelaksanaan tindakan siklus II, keadaan kelas sudah mulai kondusif, peserta didik yang tadinya pasif menjadi aktif, peserta didik terlihat senang dalam mengikuti pembelajaran. Pada saat 
mengerjakan soal tes akhir siklus peserta didik terlihat lebih lancar dalam mengerjakan soal-soal kemampuan berpikir logis. Pada siklus II ini, penerapan model pembelajaran Advance Organizer dengan media Index Card Match sudah berjalan dengan maksimal dan sudah sesuai dengan yang diharapkan. Peneliti sudah dapat mengkondisikan kelas dengan baik. Pada pembelajaran siklus II peneliti dapat menyimpulkan bahwa pelaksanaan pembelajaran dengan menerapkan model pembelajaran Advance Organizer dengan media Index Card Match sudah dikatakan tuntas/berhasil, karena hasil observasi kesesuaian peneliti dengan RPP, hasil observasi aktivitas guru, hasil observasi aktivitas peserta didik, dan hasil tes akhir siklus telah memenuhi kriteria keberhasilan yang telah ditetapkan. Hal ini dibuktikan dengan tes akhir siklus I dengan presentase ketuntasan mencapai 77,78\% dimana 21 dari 27 peserta didik yang hadir saat tes akhir siklus yang tuntas.

Dari hasil observasi dan refleksi dapat disimpulkan bahwa penerapan model pembelajaran Advance Organizer dengan media Index Card Match siklus I mengalami peningkatan pada siklus II. Peningkatan tersebut dapat dilihat baik pada keterlaksanaan pembelajaran maupun aktivitas peserta didik. Aktivitas peserta didik dalam mengerjakan soal pada siklus I sudah tidak mengalami kesulitan, dan peserta didik terlihat senang dalam mengikuti pembelajaran.

\section{SIMPULAN DAN SARAN}

Dari hasil analisis data dan pembahasan hasil penelitian, dapat disimpulkan bahwa ada proses peningkatan kemampuan berfikir logis peserta didik melalui model pembelajaran Advance Organizer dengan bantuan media Index Card Match kelas VII MTs Sunan Ampel Siman materi belah ketupat dan layang-layang tahun pelajaran 2016/2017. Dengan langkah-langkah pembelajaran sebagai berikut. (a) Presentasi Advance Organizer, guru membahas materi yang baru dengan mengaitkan materi yang sebelumnya. Kemudian guru membagi peserta didik dalam beberapa kelompok dan membagikan Lembar Kegiatan Peserta Didik (LKPD) serta media Index Card Match berupa kartu soal dan jawaban, (b) Penyajian tugas belajar, peserta didik memasangkan kartu soal dengan kartu jawaban yang cocok bersama dengan teman sekelompoknya berdasarkan jawaban yang sesuai pada LKPD yang telah dibagikan, (c) Penguatan organisasi kognitif, peserta didik mempresentasikan hasil diskusinya di depan kelas dan peserta didik diminta untuk menjelaskan hasil jawabannya dengan mengaitkan materi lama dengan materi baru.

Deskripsi peningkatannya adalah (1) ketuntasan pada tes akhir siklus I sebesar $66,67 \%$ dengan nilai rata-rata kelas mencapai 73,67. Sedangkan pada siklus II mencapai 77,78\% dengan nilai rata-rata 78,52; (2) hasil observasi kesesuaian kegiatan guru dengan Rencana Pelaksanaan Pembelajaran (RPP) pada siklus I mencapai $85,95 \%$ sedangkan pada siklus II mengalami peningkatan menjadi 87,62\%; (3) hasil observasi kesesuaian aktivitas siswa dengan Rencana Pelaksanaan Pembelajaran (RPP) pada siklus I mencapai 80,95\% sedangkan pada siklus II menjadi 87,38\%; (4) hasil persentase wawancara dari 6 peserta didik pada siklus I mencapai 66,67\% yaitu 4 dari 6 peserta didik menyatakan senang dan pada siklus II menjadi 83,33\% yaitu 5 dari 6 peserta didik menyatakan senang dengan penerapan model pembelajaran Advance Organizer dengan media Index Card Match.

Karena model pembelajaran Advance Organizer dengan media Index Card Match dapat meningkatkan kemampuan berpikir logis peserta didik, maka guru dapat menerapkan pembelajaran Advance Organizer dengan media Index Card Match di sekolah untuk memperbaiki proses pembelajaran di kelas dan peneliti yang lain dapat menerapkan pembelajaran Advance Organizer dengan materi atau media yang lain di sekolah yang lain.

Adapun saran dalam penelitian ini adalah sebagai berikut: (1) bagi guru dapat digunakan sebagai alternatif model pembelajaran agar dapat meningkatkan kemampuan berpikir logis peserta didik, (2) bagi peserta didik sebaiknya dituntut menciptakan suasana belajar yang menyenangkan serta belajar menggunakan gagasan-gagasan matematika dalam bahasa dan cara peserta didik sendiri, sehingga dalam belajar matematika peserta didik menjadi berani dan percaya diri dalam beragumen atau mengemukakan pendapatnya, (3) bagi peneliti selanjutnya yang berminat 
mengadakan penelitian tentang model pembelajaran Advance Organizer dengan bantuan media Index Card Match terhadap kemampuan berpikir logis, disarankan penelitian ini dapat dilengkapi dengan meneliti aspek yang belum terjangkau, dan diharapkan untuk menggunakan pada materi yang lain serta pada jenjang pendidikan yang lebih tinggi.

\section{DAFTAR RUJUKAN}

Ardayati. (2015). Pemanfaatan Media Index Card Match untuk Pembelajaran Bahasa Inggris di SMP. Lubuklinggau: STKIP PGRI Lubuklinggau.

Arikunto, S. (2012). Penelitian Tindakan Kelas. Jakarta: Bumi Aksara.

Basleman, A., \& Syamsu, M. (2011). Teori Belajar Orang Dewasa. Bandung: PT Remaja Rosdakarya.

Budi \& Mega. (2014). Identifikasi Kemampuan Berfikir Logis dalam Pemecahan Masalah Matematika pada Siswa Kelas VIII-1 SMP Negeri 2 Sidoarjo. Jurnal Ilmiah Pendidikan Matematika. Universitas Negeri Surabaya.

Huda, M. (2013). Model model pengajaran dan pembelajaran.Yogyakarta: Pustaka Pelajar.

Ibrahim \& Suparni. (2008). Strategi Pembelajaran Matematika. Yogyakarta: Bidang Akademik UIN Sunan Kalijaga.

Moleong, L. J. (2014). Metodologi Penelitian Kualitatif. Bandung: Remaja Rosdakarya offet. Purnomo. (2006). Matematika untuk SMP/MTs Kelas VII Semester 2. Surakarta: Teguh Karya. Sanjaya, W. (2009). Penelitian Tindakan Kelas. Jakarta: Kencana.

Sugiyono. (2015). Metode Penelitian Pendidikan. Bandung: Alfabeta. 